\title{
Historical and Theoretical Bases of Inclusive Education Development in Russia
}

\author{
Ekaterina A. Kirillova ${ }^{1}$ \\ ${ }^{1}$ Kazan (Volga region) Federal University, Kazan, Russia \\ Correspondence: Ekaterina A. Kirillova, Kazan Federal University, Kremlyovskaya Street 18, Kazan, 420008, \\ Russia.
}

Received: January 19, 2014

Accepted: February 22, 2015 Online Published: March 25, 2015

doi:10.5539/res.v7n5p31

URL: http://dx.doi.org/10.5539/res.v7n5p31

\begin{abstract}
The study of historical and theoretical bases of inclusive education emergence and development in Russia is of great urgency caused by the necessity to improve the established educational system, to work out methods and forms of education, and to spread knowledge among learners. The goal of this work is to reveal historical and theoretical bases of inclusive education development in Russia, to formulate the prerequisites of new educational system emergence and development, to characterize the modern inclusive situation in the Russian Federation. The article presents the analysis of normative and legal documentation; there has been described the main conceptual ideas of inclusive training and revealed the essence and value of inclusive education for this country. The article is of certain value for students of higher educational institutions studying the course "Vocational (speech pathology) education", the training profile "Logopedics", "Psychology for Special Needs", and pedagogical sciences. The materials of the article may be included in lecture courses of corresponding academic disciplines, and in researches.
\end{abstract}

Keywords: inclusive education, inclusive training, children with special educational needs, disabled people, history of emergence, prerequisites of development

\section{Introduction}

The issue connected with the coeducation of children with special educational needs and children without health problems has acquired more and more attention in the last few years and obtained the name inclusive. It is recognized by the world community as the most humane and efficient as it grants the right for education to everyone irrespective of compliance with or discrepancy to school system criteria; besides, it promotes the expansion of all children's personal opportunities; it helps to develop such qualities as humanity, tolerance, readiness to help (Rieser, 2013; Valeeva \& Demakova, 2015; Biktagirova \& Valeeva, 2015).

Inclusive education is such an organization of training process when all children irrespective of their physical, mental, intellectual, cultural-ethnic, language, and other features are included in the general education system and trained at the same local neighbourhood comprehensive schools with their non-disabled peers; schools they study at are of general type but they take into consideration their learners' special educational needs and render necessary support (Ainscow, 2002).

The aim of inclusive education is to eliminate social exclusion which is the consequence of negative, ill-natured attitude and lack of due response to distinctions on the basis of race, economic situation, social background, ethnic origin, language, religion, individual abilities. The process of education in many countries is carried out both in the context of formal and informal education, within families and within wider communities as well. Hence, inclusive education should not be considered as a minor issue; it should play a crucial role in ensuring high-quality education for all learners and in the creation of more inclusive societies. Inclusive education should be aimed to achieve social equality; it should be one of the elements of education throughout humans' life (Fajzrahmanova, 2014).

In Russia inclusive education is a new system where learners and teachers work at a common goal - available and quality education for all children without exception. In the Federal law "About education in the Russian Federation" the concept "inclusive education" is treated as "the ensuring of equal access to education for all learners with the variety of their special educational needs and individual opportunities taken into account"; the 
concept "a learner with health problems" implies "a human having physical and (or) psychological development problems confirmed by a psychological, medical and pedagogical commission and interfering with education without creation specific conditions".

The introduction of inclusive education has become one of the priorities of the Russian state social policy; its goal is to create such conditions for disabled children's full education and upbringing that should be adequate to their state and health. This guideline is the major one in educational policy at present.

The spread of inclusion process in our country-inclusion of children with mental and/or physical health problems in educational institutions together with their peers - does not only meet the requirements of the time, but realizes children's rights for education according to the legislation of the Russian Federation. All children, despite their physical, intellectual, ethnic, social, and other features have to be included in the general education system, should be brought up together with their peers in the area of their residence (Alekhina, 2010).

Inclusive education raises the status of children with special educational needs and their families in the society; it promotes the development of tolerance, mutual respect, mutual aid, support, responsibility, social equality (Akhmetzyanova, 2014).

The history of a new education system establishing in the Russian Federation is rather short as inclusive education has become the phenomenon of recent years; the process of its development in our country has not been finished, on the contrary, it is at its initial stages of formation, introduction and distribution. Therefore the following issue is getting relevant: what has become the basis of inclusive education emergence and development in our country; what is its origin?

The analysis of theoretical works showed that the matter has not been studied sufficiently and demands further research.

\section{Methodological Framework}

Inclusion is a social and humanistic concept which assumes the uniqueness of goal comprehension-humanization of public relations and acceptance of the right to obtain quality co-education for people with health problems. Inclusion in education is a step of an inclusion in the society, one of humanistic ideas of its development. The development of inclusive education does not mean the creation of a new system, but high-quality and systematic change of the education system in general (Nigmatov, 2014).

The following philosophical concepts have served as theoretical bases for the formation and development of inclusive education ideas in Russia: the concept of existentialism in which the person acts as an only one, unique, and free person (Jaspers, 2012; Sartre, 1989, etc.); theory of sociocultural constructivism (Berger, 1995; Luckman, 1995); the concept of individualization in training in the context of Zenkovsky (1996), Tolstoy (1989) and other's philosophical and ethical doctrines; pedagogical concepts: concepts of humanistic pedagogics (Rousseau, 1981; Disterweg, 1981; Makarenko, 1978; Sukhomlinsky, 1979, etc.); the cultural concept of personally focused education (Bondarevskaya, 2000); the concept of adaptive school (Zaruba, 1999; Kapustin, 1991, etc.); psychological concepts: cultural and historical origin of mentality and formation of the highest mental functions (Vygotsky, 1960), the concept about regularities of mental development in norm and pathology (Rubenstein, 1989; Lebedinsky, 2003; Cheverikina et al., 2014; Ibatullova et al., 2014), the concept about the leading role of education in the development (Galperin, 1985; Zakirova \& Koletvinova, 2014; Sibgatova et al., 2015; Mokeyeva, Zakirova, \& Masalimova, 2015), the concept of individuum's personalisation (Petrovsky, 1982), concepts of humanistic psychology (Maslow, 1973; Rogers, 1994); concepts of integrated and inclusive education (Rieser, 2013; Loreman, 2010; Ainscow, 2002; Malofeyev, 1996).

Conceptual ideas of inclusive education are based on the inadmissibility of discrimination of children with health problems (The Salamanca declaration, 1994) and on the necessity to include each child with health problems in the educational space (The Convention on the Rights of the Child, 1989).

One of the main approaches applied in inclusive educational environment is the theory and practice of problem based learning (Loreman, 2010). The Concept of this guideline in domestic pedagogics is based on S. Ya. Rubenstein's researches; the theory and practice of problem based learning are explained in the works of Matyushkin (2008), Makhmutov (1977), and other researchers. The practice of problem based learning at elementary school is presented in works of Bryzgalova (1998) and other authors.

\section{Prerequisites of Inclusive Education Emergence and Development in Russia}

The history of inclusive education emergence dates back to the XVIIth century when the term "integral" was introduced in mathematics. By the XXth century the term "integrate" gradually gets into philosophy, psychology, 
sociology, and then into pedagogics. Then the term "social integration" appeared in pedagogics. In the dictionary of foreign words "integration" [fr. intégration - lat. integratio completion, restitution-integer "entire"] means: 1 . the combining of two or more things together so that they work together effectively; 2 . when people become part of a group or society and are accepted by them. Initially this term was used in the USA to designate racial, ethnic minorities; later it was applied to children of immigrants, and only in the last decades (since the 60s of the XXth century) the term was included into speech on the European continent and was applied in the context of problems concerning people with health problems (disabled people).

Russia fell behind the research during this period. When the whole world was discussing integrated education of children with health problems (the 60s of the XXth century), Russian teachers practiced isolated education for children with special educational needs, i.e. the medical model of learning was applied that led to such children's complete isolation. In the form of the experiment the idea of integrated education was the subject of research in the scientific research institute of defectology of APS in the USSR (the 70s).

In the 80 s of the XXth century a new terminology "inclusion" appeared in the USA already; the "model of normalization" integrating people with health problems into public life became characteristic for Russia at that time (Akimova, 2011).

The term "inclusion" got into pedagogical practice in Russia only in the 90s of the XXth century after there had been elaborated new international documents which became the guide for action for a number of developed countries.

Therefore the development and distribution of normative and legal documents and acts in the western world should be considered as one of the prerequisites of inclusive education emergence in Russia: The Universal Declaration of Human Rights (UNO, 1948) states in article 26 the right of everyone to free compulsory elementary education "accessible to all on the basis of merit"; The Declaration of Child Rights (UNO, 1959) where principle 7 proclaims: "The child is entitled to receive education... He shall be given an education which will promote his general culture and enable him, on a basis of equal opportunity, to develop his abilities, his individual judgement, and his sense of moral and social responsibility, and to become a useful member of society"; UNESCO Convention against Discrimination in Education (1960), UN Declaration on the rights of mentally retarded persons (1960) annunciates the right of each mentally retarded person to "... such education, training, rehabilitation and guidance as will enable him to develop his ability and maximum potential". The World Programme of Action concerning Disabled Persons (1982) proclaims that the creation of equal opportunities implies the process, by means of which such common systems of society as access to education are made available for all. The World Conference on Special Needs Education (Spain, Salamanca, 1994) introduced the term "inclusion" into international use and proclaims the principle of inclusive education (Kirillova, 2014).

In this regard, the Convention on the Rights of the Child was signed in the USSR in 1990; in 1992 the Law "About Education in the Russian Federation" appeared; in 2008 Russia signed the Convention on the rights of disabled people. Besides in 2008 there were approved Recommendations of the Ministry of Education and Science of the Russian Federation concerning the establishing of conditions for education of children with special health needs in the Russian Federation. In December 2010 the State Duma of the Russian Federation gets to practical work to change the Russian legislation according to the Convention on the rights of disabled people. In 2012 there were made amendments to the Law "About Education in the Russian Federation" connected with inclusive education of children with health problems.

Thus, the legal development and legal maturity of foreign countries could not but impacted the development of educational and social policy of Russia.

But the emergence of such legislative base is impossible without internal changes of the society and state, awareness of the necessity to change the attitude towards disabled people and people with special educational needs, recognition of their right for full-fledged life. All this makes the humanistic prerequisite of inclusive education establishing in Russia and in the world as well.

The ideas of inclusive education in Russia are supported actively due to the following social reasons.

In Russia, as well as around the world, the increase in number of children born with deviations in development is observed: hearing and eyesight impairment, mental development disorder, musculoskeletal disorders, severely impaired speech skills due to anatomo-physiological features of articulation organs or cerebral affection. Education and upbringing of such children was carried out in specialized (correctional) kindergartens and schools; it is still conducted in such correctional institutions. Many parents of children with health problems oppose such education, they are against isolation of children from society; they actively support inclusive 
education because at an inclusive school nobody will label their child as an invalid, as a person different from others. In educational inclusion all children, no matter disabled or non-disabled, have equal rights, and the priority is given to the personality, their human qualities: kindness, mutual help, friendship, openness, honesty and to many other features. Such desire of parents may be explained as inclusive education is the opportunity to attend a nearby school, without being separated from relatives for a long time, to study with friends and children from the house, it is the opportunity to communicate with peers, to participate in common holidays and events, it is the opportunity to lead full-fledged life (Akhmetzyanova, 2014).

In Russia the first inclusive educational institution appears in the early 90s of the XXth century. Thus in Moscow in 1990 at the initiative of the Moscow Center of medical pedagogics and parental public organization there appears the first school of inclusive education "Kovcheg" (Ark) (No. 1321). The school receives its name from the European public organization "Kovcheg" giving help to physically disabled people. Initially there were ten learners in class among whom there was one child with developmental problems. Later children with rather serious diseases such as autism, schizophrenia, Down syndrome, cerebral spastic infantile paralysis, hearing disorder began to attend this school. The aim of such school is education and social adaptation of children irrespective of the level of their psychophysical development, upbringing of humanity and tolerance to each other. Since 2006 the program of inclusive education started its implementation in St. Petersburg (Tsivilskaya, 2014).

Now in Russia, there are many educational institutions working according to the program of inclusive education. It is introduced as an experiment in educational institutions of various types in a number of subjects of the Federation: Arkhangelsk, Vladimir, Leningrad, Moscow, Nizhny Novgorod, Novgorod, Samara, Tomsk and other areas. The implementation of the Inclusive Education project has begun in Tatarstan, Chuvashia, Mari El, Udmurtia, Bashkortostan and other republics as well.

Thus, inclusive education gets the increasing support in our country and has become the priority direction of educational policy of each subject of the Russian Federation because the modern society needs now such system of education which is based on respect, tolerance, humanity. It has gained such priority because this system of education adapts to the child's needs, but not vice versa. Advantages are available for all children, but not only for some special groups; new approaches to education are often used, variable forms and methods of upbringing and education are applied, children with special needs may be in the group all the time or some time, they are learning with support and according to their individual curriculum. Teaching is conducted in the way that is the most comfortable for each specific child.

\section{Discussions}

The topic of inclusive education is widely covered in works of many Russian pedagogues, psychologists, scientists, but in most cases authors work at a particular sphere of inclusive education without studying its historical background. The following aspects are investigated: psychological and pedagogical escort of children with special health needs (Akhmetzyanova, 2014; Tvardovskaya, 2013; Fayzrakhmanova, 2014); their socialization (Akatov, 2003); educational activity with "special" children (Nigmatullina, 2014; Alekhina, 2010; Tsivilskaya, 2014), technologies of the educational process organization, prospects of staff training for working with disabled children (Boltakova, 2014; Nigmatullina, 2014).

\section{Conclusion}

Education has always been an integral part of complex historical processes connected with the functioning and development of culture in general. The history of education for people with special educational needs has passed a long way in Russia: from isolation to inclusion. There have been elaborated various forms and methods aimed to teach such people. Finally the society has created an ideal model of education.

Inclusion is the opportunity for all learners to participate in the life of kindergarten, school, institute, in preschool and school life. The aim of inclusive school is to give all pupils the chance for a full-fledged social life, participation in the collective, local community, thus providing interaction and care of each other as members of the community (Prochukhayeva, 2010).

The main requirement to the modern education is that it has to become humanistically focused, to consider a human as the main value, to be aimed at personality development. Such approach regards any forms, methods, technologies of education in the context of one of the basic tasks of education - to provide the most favorable conditions for self-development and adaptation.

At present inclusive education in our country is getting more and more spread. It is supported by legislation, proved by the international requirements and processes of the world integration. Foreign experience shows that 
this project will demand a lot of time and participations of everybody.

Its main goal is to arrange the educational process in such a way that all children should have the opportunity to study, develop, communicate all together, to be happy and contented, and the quality of education should be at a high level.

Inclusive education in Russia is urged to solve the following problems:

- Creation in educational institutions of specific educational environment conditions which do not limit physical access of disabled learners (access roads, wide exits, elevators, adapted bathrooms, corresponding equipment in educational classes);

- Development of specialized services for children; training and qualification of corresponding staff (psychological, pedagogical, logopedic, social services);

- Arrangement of psychological and pedagogical support of educational process, appropriate assistance to children, parents and teachers;

- Elaboration of specialized programs and techniques of training in an inclusive educational institution;

- Teachers' professional competence improvement;

- Parents' involvement in the educational process;

- Interaction of experts of various profiles;

- Formation of educational process participants' tolerance to people (children) with special educational needs;

- Perfecting of legislative base;

- Ensuring of individual pedagogical approach to the child with health problems; peculiarities of health should be taken into account.

Inclusive education is a new stage of cultural, moral, social, political development of the Russian society which has been brought to life by legal, humanistic, social reasons.

The development of inclusive education in Russia is a long and labour consuming process; it demands from all its participants great patience, intellectual and spiritual efforts aimed at the achievement of the highest result of the whole inclusive educational system - formation of the personality, "able to adapt to the varieties of the world, to interact with others, tolerant and sociable, thinking independently, and capable to empathy" (Nigmatov, 2014).

Thus, it is possible to draw a conclusion that Russian inclusive education, despite its recent emergence, has already had its history and theoretical bases, the further formation and development of which will depend on all participants of the educational process.

\section{Acknowledgments}

The work is performed according to the Russian Government Program of Competitive Growth of Kazan Federal University.

\section{References}

Ainscow, M. (2002). Understanding the Development of Inclusive Schools. Taylor \& Francis Group.

Akatov, L. I. (2003). Social rehabilitation of children with health problems. In Psychological foundations: Study guide for students of higher educ. institutions. Moscow: VLADOS.

Akhmetzyanova, A. I. (2014). Correction of sensorimotor functions of pre-lingual children with cerebral palsy in the context of Lekoteka. World Applied Sciences Journal, 29(6), 743-746.

Akhmetzyanova, A. I. (2014). Spatial and temporal elements of anticipation consistency of children with general speech retardation. American Journal of Applied Sciences, 11(7), 1031-1035. http://dx.doi.org/10.3844/ajassp.2014.1031.1035

Akhmetzyanova, A. I. (2014). The Development of Self-Care Skills of Children with Severe Mental Retardation in the Context of Lekoteka. World Applied Sciences Journal, 29(6), 724-727.

Akimova, O. I. (2011). Inclusive education as the modern model of education. In Inclusive education: Methodology, practice, technologies. Moscow: Moscow city psychology and pedagogical university.

Alyokhina, S. V., \& Semago, N. Y., (2010). Inclusive education. Moscow: School Book center.

Berger, P., \& Luckmann, T. (1995). The Social Construction of Reality: A Treatise on Sociology of Knowledge. Moscow: Medium. 
Biktagirova, G. F., \& Valeeva, R. A. (2015). Formation of University Students' Readiness for Parenthood. Review of European Studies, 7(4), 93-97. http://dx.doi.org/10.5539/res.v7n4p93

Bondarevskaya, E. V. (2000). The theory and practice of personally focused education. Rostov on Don: Publishing house of Rostov ped. un-ty.

Bryzgalova, S. I. (1998). Problem based teaching at elementary school: Study guide (2nd ed.). Kaliningrad: Kaliningr. un-ty.

Cheverikina, E. A., Rakhimgarayeva, R. M., Sadovaya, V. V., Zakirova, V. G., Starodubets, O. D., \& Klemes, V. S. (2014). Socio-psycological characteristics of college students who are prone to addictions. American Journal of Applied Sciences, 11(8), 1412. http://dx.doi.org/10.3844/ajassp.2014.1412.1417

Disterweg, A. (1981). Guide for the instruction of German teachers. In A. I. Piskunov (Ed.), Anthology of foreign school and pedagogics history. Moscow.

Fajzrahmanova, A. T. (2014). On organization of the inclusive educational environment in higher educational institutions of the Russian Federation. Life Sci J., 11(11s), 59-62

Galperin, P. Y. (1985). Methods of teaching and child's intellectual development. Moscow: Publishing house of Moscow un-ty.

Ibatullova, Y. T., Vasyukhno, I. O., Frolova, A. V., Mukhametzyanova, F. G., Zelenkova, E. V., \& Sadovaya, V. V. (2014). Interrelation of social and psychological adaptation and tendency to deviant behavior of students. Asian Social Science, 11(2), 290-296.

Jaspers, K. (1932/2012). Philosophy. Enlightenment of Existence. Moscow: Publishing house of Kanon+RSDP "Rehabilitation".

Kapustin, N. P. (2001). Pedagogical technologies of adaptive school. Moscow: "ACADEMA".

Kirillova E. A. (2014). Prerequisites of inclusive education emergence and development in Russia. In A. I. Akhmetzyanova (Ed.), Innovative forms and technologies in complex escort of children with deviations in the development: Materials of the International scientific and practical conference of students, graduate students and young scientists (pp. 39-42). Kazan: Publishing house of Kazan. un-ty.

Lebedinsky, V. V. (2003). Violations of mental development at child's age: Study guide for graduate students of psych. faculty. Moscow: Academy.

Loreman, T. et al. (2010). Inclusive education: Supporting diversity in the classroom (2nd ed.). London and New York: Routledge.

Makarenko, A. S. (1978). Selected pedagogical compositions. Moscow.

Makhmutov, M. I. (1977). The organization of problem based training at school. Moscow.

Malofeyev, N. N. (1996). Special education in Russia and abroad: In 2 parts. Part 1. Western Europe. Moscow: Pechatny dvor.

Maslow, A. (1973). Dominance, Self-Esteem, Self-Actualization. California.

Matyushkin, A. M. (2008). Problem situations in thinking and training. Moscow: Direktmedia Publishing.

Mokeyeva, E. V., Zakirova V. G., \& Masalimova, A. R. (2015). Tolerant Pedagogic Space as a Condition of Non-Violence Position Education among Elementary School Pupils. Review of European Studies, 7(4), 216-220. http://dx.doi.org/10.5539/res.v7n4p216

Nigmatov, Z. G. (2014). Humanitarian Technologies of Inclusive Education. Procedia-Social and Behavioral Sciences, 131, 156-159. http://dx.doi.org/10.1016/j.sbspro.2014.04.096

Nigmatullina, I. A. (2014). Use of art and therapeutic technologies in the work of lekoteka experts with children having impairments of the emotional volitional sphere. Problems of Modern Psychology, 24, 541-553.

Nigmatullina, I. A., \& Boltakova, N. I. (2014). About integration of educational, self-educational and research activity of future teachers-logopedists. Education and self-development. Scientific pedagogical and psychological journal, 3(41), 46-50.

Petrovsky, A. V., \& Petrovsky, V. A. (1982). The individual and their need to be the personality. Issues of philosophy, 3, 44-53.

Prochukhayeva, M. M., \& Samsonov, E. V. (2010). Inclusive education. Issue 4, Methodical recommendations on the organization of inclusive educational process in kindergarten. Moscow: Center School book. 
Rieser, R. (2013). Teacher Education for Children with Disabilities, Literature Review. For UNICEF REAP Project.

Rogers, C. R. (1994). On Becoming a Person: A Therapists View of Psychotherapy. Moscow: Progress.

Rubenstein, S. L. (1989). Fundamentals of general psychology. Moscow: Pedagogics.

Rousseau, J. J. (1981). Pedagogical essays: In 2 v. Moscow: Pedagogics.

Sartre, J. P. (1989). Existentialism is a humanism. In Twilight of gods (pp. 319-344). Moscow: Politizdat.

Sibgatova, K. I., Sabirov, I. T., Sadovaya, V. V., Vlasova, V. K., Leyfa, I. I., Yatsevich, L. P., \& Fassakhova, G. R. (2015). Pedagogical Potential of the Career Guidance Course "Professional Career Planning" to Form Pupils and Students? Self-Determination in the Integrated System "School-Vocational College". Review of european studies, 1(7), 80-85.

Sukhomlinsky, V. A. (1979). Selected pedagogical essays. Moscow.

Tolstoy, L. N. (1989). Pedagogical essays. Moscow. Pedagogic.

Tsivilskaya, E. A. (2014). The issue of inclusive education in Russia (for example, the implementation of integrated education of children with disabilities in the Republic of Tatarstan). European Journal of Science and Theology, 10(6), 213-216. Retrieved from http://www.ejst.tuiasi.ro/Files/49/Contents\%2010_6_2014.pdf

Tvardovskaya, A. A. (2013). Program support of thinking activity development of primary school children with cerebral palsy. International Journal of Learning and Teaching, 5(2), 50-54.

Valeeva, P. A., \& Demakova, I. D. (2015). Humanization of Education in the Context of Janusz Korczak Pedagogical Ideas. Review of European Studies, 7(4), 161-171. http://dx.doi.org/10.5539/res.v7n4p161

Vygotsky, L. S. (1960). The Development of Higher Psychological Processes. Moscow: Publishing house of the Academy of ped. Sciences.

Zakirova, V. G., \& Koletvinova N. D. (2014). Paradigm of future primary school teachers' vocational training. Life Science Journal, 11(4), 441-447.

Zaruba, N. A. (1999). Modern school: Reforming stage. Kemerovo.

Zenkovsky, V. V. (1996). Problems of education in terms of Christian anthropology. Moscow: School Press.

\section{Copyrights}

Copyright for this article is retained by the author(s), with first publication rights granted to the journal. This is an open-access article distributed under the terms and conditions of the Creative Commons Attribution license (http://creativecommons.org/licenses/by/3.0/). 